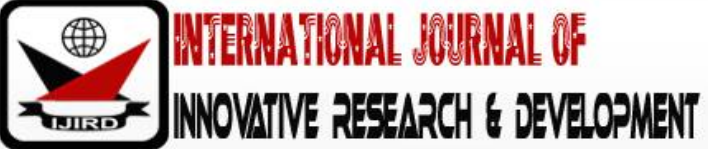

ISSN 2278 - 0211 (Online)

\section{Determinants of Auditors' Selection among SMEs in Lagos Metropolis, Nigeria}

\author{
Dr. Aladejebi Olufemi \\ Managing Consultant, Department of SMEs, Great Business Clinic Ltd (TGBCL), Nigeria
}

\begin{abstract}
:
This paper examines the determinants of Auditors' selection among Small and Medium Enterprises (SMEs) in Lagos metropolis. The study was based on Primary data collected through structured questionnaire divided into two parts. Part a was designed to collect general information, while Part B contained the ten factors that determine auditor's selection. The questionnaire on the determinants of auditor's selection among SMEs was adapted from Olowookere \& Inneh (2016) and Almer, Philbrick, \& Rupley (2014). 300 copies of the questionnaire were administered to respondents who were purposively selected among SME owners in 4 areas of Lagos metropolis (Alaba, Ikeja, Lagos Island, and Surulere) with 75 questionnaires for each area with five-point Likert. 236 questionnaires were returned and analyzed SPSS was used to analyze the data collected. The study inferred that the top factors that determine the choice of auditors among SMEs are the referral by friends and Associates, quality of the written proposal, Long term relationship with the current auditor and owner's preference for specific auditor. This study will be useful to Owners' of SMEs, auditors, Accountancy Professional Bodies, and SME trade groups.
\end{abstract}

Keywords: Small business, auditors' choice, auditors' independence, quality of audit

\section{Introduction}

A professional external auditor carries out an audit taking into consideration specific rules and regulations guiding the preparation of financial statements of a company, government entity and other legal entities or organization and is expected to be independent of the entity being audited (Gahman \& Ali, 2015). Engaging an accounting firm is a major corporate governance apparatus to ameliorate many distortions which can come up in a company's internal environment (Evangelia, 2013). The Nigerian laws make it mandatory for companies to have their financial statements audited by an independent public accountant. In Nigeria, more than 2,000 audit firms currently provide audit services to domestic listed and unlisted companies (Olowookere \& Inneh, 2016). Auditing plays the role of improving the rating of the financial statements since high rating reporting can lead to a reduction in information asymmetry problems between a firm and providers of financing (Olowookere \& Inneh, 2016). Also, according to Knechel, Niemi, \& Sundgren (2008), audit provides benefits that are internal to the company, for example, reduction in internal agency problems, regulatory compliance, and improvements in process effectiveness. The big 4 audit firms rarely audit SMEs in Nigeria, except where foreign funding is involved. Wallace (1981) mentioned benefits that audit brings improvements in operational efficiency, effectiveness due to auditor evaluation of internal processes; deterrence of management malfeasance, increase compliance with legal and regulatory constraints, smaller nonpublic companies have little separation between ownership and management.

According to Ilaboya \& Ohiokha (2014), auditors express their audit opinions on a financial statement presented to them based on audit evidence. The objective of an audit, therefore, is to plan and carry out the audit to gather relevant audit evidence that is enough to support the opinion expressed in the auditor's report. An auditor is expected to comply with the code of ethics as issued by the International Federation of Accountants (IFAC) governing in 1997 auditor's professional responsibilities: independence, integrity, objectivity, professional competence and due care, confidentiality, professional behavior, and Technical standards. These principles are imperative in maintaining public confidence in the work of the external auditor (Ohiokha \& Akhalumeh, 2013). The basic objective for preparing financial statements is to provide information useful for making economic decisions (Olagunju, 2011). The objective of auditing a financial statement is to help the auditor to express an opinion on whether the financial statements are well prepared or otherwise and also in accordance with the auditing standard. Audited financial statements should have these qualities: understandable, timely, reliable, relevant \& material, comparable, meets the international standard (Olagunju, 2011). Members of two professional bodies that are licensed to audit companies in Nigeria are members with practicing license of Institute of Chartered Accountants of Nigeria (ICAN) and Association of National Accounts of Nigeria (ANAN). As stipulated by CAMA (2004), it is important that every Limited Liability Company chooses an external auditor who is expected by law to give an independent opinion on the state of affairs of the company (Babatolu, Aigienohuwa, \& Uniamikogbo, 2016). 
SMEs account for a greater percentage of all businesses in virtually every economy and generate the majority of private sector employment and output (Acho \& Abuh, 2018). SMEs constitute a greater percentage of all the registered companies in Nigeria, many of the SMEs evolved from cottage industries to small enterprises and from small scale to medium scale enterprise (Yunusa \& Paul, 2018). In Nigeria, most SMEs prepare audited account merely to satisfy statutory requirements for returns to Federal Inland Revenue Service (FIRS) and Corporate Affairs Commission (CAC).

\subsection{Statement of the Problem}

The basis why a firm chooses a specific auditor may be complex and are likely to vary across organizations. (Knechel, 2002). An audit is just one of the professional services rendered by an accounting firm. Though most SMEs in Nigeria do not hold annual general meetings, they still appoint auditors in order to file their Tax Returns to Federal Inland Revenue. Without Filing Audited Accounts for tax purposes, there is a likelihood that some small businesses that are limited liability companies will not prepare audited financial statements. The growing need for more transparent and fairly presented financial reports enhance the importance of external auditing and Audit quality (Aslan \& Aslenertik, 2017). In small companies, the possibility of a material misstatement arising and the possibility of the Accounting control detecting any material misstatement may be high (Collis, Jarvis, \& Skerratt, 2004). The demand for external audit may be attributable to management's need for a check on internal controls to reduce the chance of material error (Collis, Jarvis, \& Skerratt, 2004). Abid, Shaique, \& Anwar Ul Haq (2018), showed that big four auditors provide better assurance services to their clients. Zhang et al. (2010) revealed that firms with less disclosure and transparency select small and poor-quality audit firms as their auditor compared to other firms. Lin and Liu (2009), in their research, showed that companies with poor corporate governance laws select small audit firms that their work quality is lower than that of big firms. They also revealed that whenever corporate governance improves in a company, there is an increase in the possibility of selecting larger firms. Haron, Ismail, Ganesan, \& Hamzah, (2016) mentioned that the distinction between private and public organizations are so wide that one cannot depend on the findings for public organizations without taking into cognizance what one wants to know in auditing of private organization whether auditing is statutory or not. Users of companies' financial information such as creditors, potential investors, shareholders, government, staff, and the general public depend on the external auditor to present an unbiased and independent audit report (Gahman \& Ali, 2015). Management may window dress the accounts to hide their lack of success. Therefore, the stakeholders need assurance from a third party that the financial statements show a true and fair view (Okpala, 2015). The credibility of audited financial statements is important without which a financial statement may not worth more than a mere tissue paper (Olagunju, 2011).

\subsection{Objectives of the Study}

The objective of this study is to examine the factors that determine the choice of Auditors among SMEs in Lagos Metropolis. The findings of this study will provide insights into what determines the choice of audit firms among SME in Lagos metropolis. The study will also contribute to the growing body of literature on the determinant of choice of auditors by SMEs as there is a paucity of data on determinants of choice of auditors by small firms. Most of the literature available on the topic is on determinants of choice of auditors by big firms and publicly quoted firms. The other objectives of this study include: what affects the credibility of audited financial statements, recognition of the audit firms licensed to practice in Nigeria, identification of factors that affects auditors' independence and audit quality

\section{Literature Review}

\subsection{Theoretical Framework}

Many theories guide the concept of auditing. The theories include Agency theory, Quasi-Judicial theory, Policeman's theory, Moderator of claimant's theory, Theory of inspired confidence, and Credibility theory.

\subsubsection{Theory of Inspired Confidence}

This theory came into existence as a result of a series of essays published by Limperg in 1932. Limperg (1932) asserted that the auditor's functions are as a result of societal expectation of expertise and independent opinion based on examination. Confidence is reposed by the society in the auditor to give an independent opinion. Limperg (1932) further stated that confidence could be betrayed under two circumstances i.e., if the expectation of the society is too high exceeding what the auditor can do or when the auditor underperforms thus betraying the confidence reposed in him by the society. Theory of inspired confidence is also known as the theory of rational expectations.

\subsubsection{The Policeman Theory}

The most widely known theory of auditing until the 1940s was that the auditor was responsible for the discovery of fraud like a policeman. The auditor was expected not only to focus on the arithmetical accuracy but also on prevention and detection of fraud (Adeyemi \& Olowoookere, 2011). Auditing literature is against this theory. The management is expected to be responsible for the prevention and detection of fraud and irregularities. The auditor's work does not include the search for fraud, except it is inclusive in terms of engagement. Meanwhile, if the audit is adequately carried out, it is expected that the work of the auditor should uncover fraud and irregularities if they exist. (Adeyemi \& Olowookere, 2011). 


\subsubsection{The Lending Credibility Theory}

The main aim of this theory is that an audit adds credibility to financial statements. The selling point of the auditor is to apply his technical competence to verify a financial statement so that the users of accounts can rely on the audited financial statements (Okpala, 2015).

\subsection{Conceptual Framework}

This study on the determinants of choice of auditors by SMEs can be conceptualized in a framework revealing the relationship between the independent variables and the dependent variable outcome.

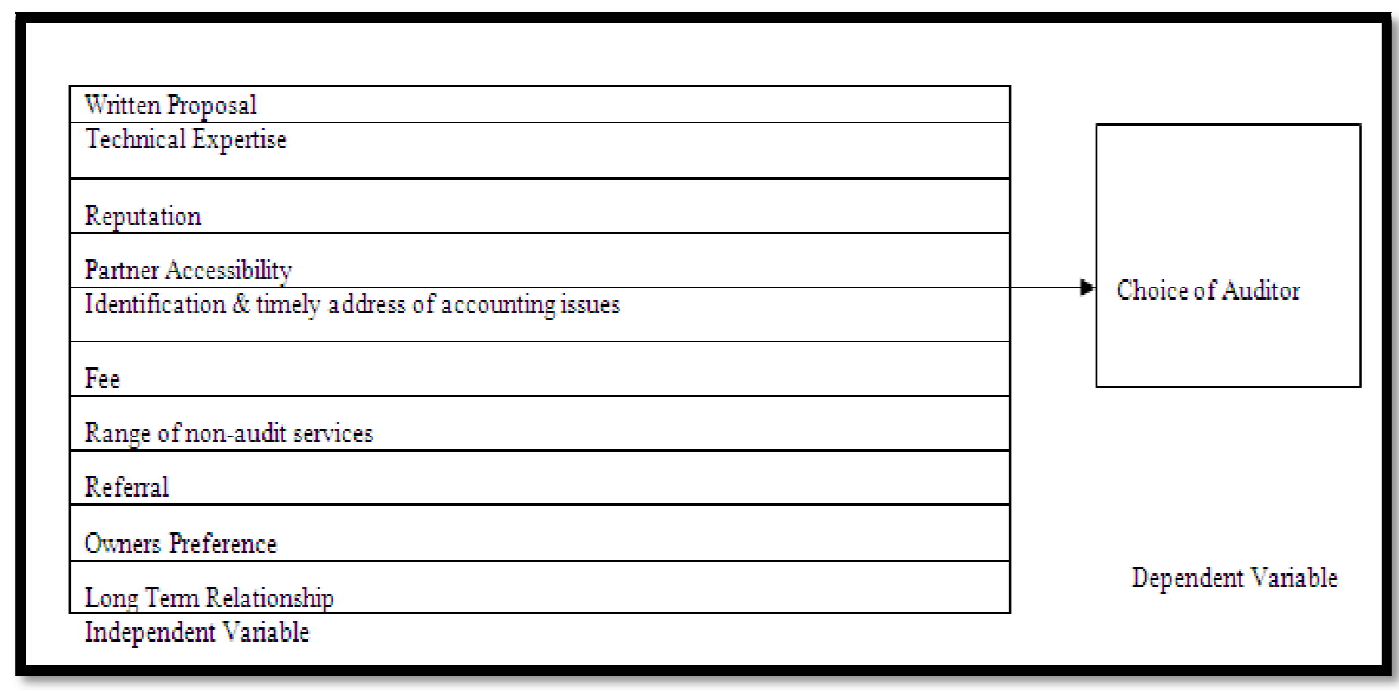

Figure 1: Conceptual Framework

\subsection{Importance of Small Business}

The definitions of SMEs vary from country to country. In defining SMEs, references are made to a member of employees, sales turnover, the value of assets, investment outlay, or a combination of these measures. (Yunusa \& Paul, 2018). SMEs are the engine of economic growth in Nigeria (Akinwale \& Adepoju, 2019). According to the Small and Medium Enterprises Development Agency of Nigeria (SMEDAN), SMEs employs 80\% of Nigeria's workforce (SMEDAN, 2013). There are three categories of SMEs in Nigeria: Micro-enterprises have 1-9 workers, Small enterprises have 10 to 49 workers, and medium enterprises with 50 to 200 workers (SMEDAN, 2013). 80\% of SMEs fail within the first five years (Adebisi \& Gbegi, 2013). According to Kehinde, Abiodun, Adegbuyi, \& Oladimeji, (2016), the following are the contributions of SMEs to Nigeria's economic development: Employment generation, technological innovation, improved standard of living, poverty reduction, creation of wealth, and provision of technical innovation. According to Olomu, Akinwale, \& Adepoju (2016), SMEs in Nigeria have been experiencing the following challenges: inadequate infrastructure, poor access to bank credit, multiple taxes, inadequate managerial and entrepreneurial skills, inability to compete in international market, limited capacity for research and development, low adoption of technological innovation, erratic power supply, lack of support from government, limited demand for products and services. SMEs form the vast majority of businesses globally, very few of them last very long, with a majority of them packing up within three years of starting due to internal and external barriers (Abe \& Proksch, 2017). Some of the internal obstacles include lack of managerial skills, inappropriate marketing strategies and poor customers' service (Rahman, Uddin, \& Lordorfos, 2017), while the external barriers include fierce market competition, high cost of business registration, limited access to finance, and lack of government support (Neirotti, Raguseo, \& Paolucci, 2018).

\subsection{History and Definition of Audit}

According to Jayeoba \& Ajibade (2016), the word "audit" comes from the Latin word audire, meaning "to hear" "to listen." Tanko (2011) observed that auditing has its history to a large extent, determined by the history of accounting as accounting translated and culminated with the development of the world economy. According to Jayeoba \& Ajibade, (2016), auditing process was said to have begun by about 400BC where among the ancient Egyptians and Babylonians they had auditing systems for checking movement in and out of storehouses. Before independence in 1960, audit practice in Nigeria followed the British system as most accountants in Nigeria then was British trained (Abdul Ganiyu, 2013). Akintola Williams \& Co. (now Deloitte) is the oldest indigenous firm in Nigeria, established in 1952 by Chief Akintola Williams popularly referred to as the doyen of the Accountancy profession in Nigeria (Jayeoba \& Ajibade, 2016).

According to Ajayi (1997), some British trained Nigerian accountants came together to form the association of Accountants in Nigeria (AAN) in 1960. This metamorphosized into the Institute of Chartered Accountants of Nigeria (ICAN) in 1965 by an act of parliament number 15 with 250 members. The Association of National Accountants of Nigeria (ANAN) was formed in 1979. Both ICAN and ANAN are the only two professional Accountancy bodies recognized in Nigeria to carry out audit practice. The International Audit and Assurance Standard Board (IAASB), a sub-committee of the International Federation of Accountant (IFAC) defined auditing as an independent examination of, and expression of opinion on the financial statements of a business enterprise by an appointed auditor in accordance with his terms of 
appointment and in compliance with the relevant statutory and performance requirements. Power (1999), defined auditing as a systematic and independent examination of books, accounts, vouchers, and documents of a firm to ascertain how far the financial statements present a true and fair view of the concern. According to Eluyela \& Ilogho (2016), the auditing profession is guided in standards, whether issued by local or international bodies, the outcome of the standards is to have an impact on the activities and behavior of auditors. Anderson, Maletta \& Wright (1998) noted that independent auditors are charged primarily with the responsibility of reporting on the financial statements of organizations and state whether or not in their opinion, the financial statements show a true and fair view of the profit or loss and the financial position of the company.

\subsection{Determinants of Choice of Auditors}

According to Haron, Ismail, Ganesan, Hamzah (2016) publicly listed firms face scrutiny from stock exchanges, regulators, and market participants, and they are characterized by the separation of ownership and control. SMEs, on the other hand, are much less regulated. SMEs are less exposed to market forces, publicity, litigation, and operate in a much less regulated environment (Haron, Ismail, Ganesan, Hamzah, 2016). Therefore, there are different market segments for audit services for listed and large companies and those of SMEs. Olowookere \& Inneh (2016) mentioned that auditor choice is determined by three possible factors- audit environment, audit firm characteristics, and finally, client characteristics. In Finland, Knechel, Niemi, and Sundgren (2008) analyze the auditor choices of a sample of 2,333 majorly SME firms. They find that among the smaller firms, the choice to hire a certified auditor relates to the level of complexity in the organization as measured by size and extent of the workforce. In a study carried out by Baldacchino and Cardona (2011), it was found that the choice of auditors was determined based on the quality of service. Quality is a function of a sound working relationship between auditors and clients and of auditor availability. According to De Ruyter \& Wetzels (1999), due to high competition in the audit market, audit firms are learning that the way toward is to establish long-term relationships with their clients. In a client-auditor relationship, past interactions will affect current, and future exchanges and are, therefore, not a onetime experience. Every auditor-client relationship which is formed is unique and evolves independently from the audit firm or client culture to which it relates (Kleinman \& Palmon, 2001). In Europe, there is a mandatory rotation of audit firm among European union member states (Grima, Romānova, Bezzina, \& Dimech, 2016. Though it has been proved that the quality of audit improves over time due to a better understanding of client business by the auditor (Lal Joshi, Al Ajmi, \& Bremser, 2009; Cameran, Prencipe, \& Trombetta, 2014; Boldeanu \& Tache, 2016). Almer, Philbrick, \& Rupley, (2014) identified the importance of an audit firm's reputation for strong industry experience and technical expertise, ability to identify and address accounting issues on timely basis, accessibility of partners, effective liaise of partner with the national technical office and the quality of written proposal as some of the determinants of choice of auditors. The cost of an audit may be a determining factor (Olowookere \& Inneh, 2016). A transparent selection that enhances audit quality and ensures auditor independence entails a good selection process (Federation of European Accountants, 2013)

\subsection{Auditors' Independence}

Auditors' independence refers to the ability of the external auditor to act with integrity and impartiality during his/ her auditing functions (Akpom \& Dimpkpah, 2013). Independence of auditors is the cornerstone of the auditing profession and the basis of trust by the society (Abdul Nasser, Mustapha, and Hudaib, 2006).

According to Barkes, Simnet \& Urquhart (2002) auditors independence is vital to Auditing. Auditors are expected to be and be seen to be independent both in action and in deeds. Any action of either the auditor or the management may impair this independence should be avoided (Ebo, 2016).

Al-Ajmi \& Saudagaran (2011) concluded that the size of an audit firm is one of the factors affecting the perception of auditor independence. That being a sole practitioner and being a small, and local audit firm impairs auditor independence. According to Baldacchino, Caruana, Grima, \& Bezzina, (2017) the following elements may impact the working relationship between auditors and clients: Confidentiality, communication, competence, Trust, Communication Barrier, Commitment, Cooperation, Adaptability towards change, Respect, Objectivity and Integrity, Accessibility and Personal Approachability. Some studies are in support of long-term client auditor relationships (Suryanto, 2016; Theriou, 2015; Budik \& Scholoss berger, 2015; Rupeika -Apoga \& Nedovis, 2015; Thalassinos \& Liapis, 2014; Fontaine, Herda, \& Letaifa, 2013; Baldacchino \& Cardona, 2011) while Bamber \& Venkararaman, 2005 believed that auditors familiarity with clients might pose a danger to the principle of independence of Auditors. Adeyemi and Okpala (2011), mentioned that an audit firm's tenure could lead to loss of auditor's independence. A long-standing audit-client relationship could lead to an alignment of the auditor's interest and that of its client, which makes genuinely independent behavior of the auditor a probability. The conclusion from some previous research shows a positive correlation between audit firm size with auditor independence (Abu Bakar \& Ahmad, 2009; Abu Bakar, Abdul Rahman \& Abdul Rashid, 2005, Gul, 1989). It has been found that the bigger an audit firm, the higher the level of auditors' independence as small audit firms succumb to the pressure from management compared to large audit firms. Though a court case between Arthur Anderson and Eron challenged the assumption that being a large firm does not guarantee the resistance to pressures from clients (Abu Bakar \& Ahmad, 2009). Ikharo (2015), stated that a longer tenure of the auditor might bring about increased knowledge of client's business, which may improve his ability to discover fraud. This will reduce managers' tendencies towards fraud and irregularities. On the other hand, long tenure of an auditor may breed familiarity which may bring about undue sympathy by the auditor for the client, thereby affecting his duty in issuing qualified audit report whenever the need arises. (Ebo, 2016). 
Abu Bakar and Ahmad (2009) asserted that firms with a large proportion of its audit fee from a single client are always afraid of losing such client; therefore, there is a risk of getting their independence jeopardized. Choi, Kim and Zang (2010) concluded that the threat of client importance to auditor independence is consistent with the view that abnormally high audit fees are seen as a red flag while at the same time abnormally low fees should also be suspected as it may suggest strong client bargaining power, which may impact negatively on the independence of auditor and in turn affect audit quality (Lin and Tepalagul, 2014). Large international accounting firms have established brand reputation and had motives to maintain it by providing high-quality audit. Lack of financial affiliation with the client makes bigger auditors more independent (Jeong \& Rho, 2004). Regulators believe the rotation of auditors as a solution for auditor's independence (Haron, Ismail, Ganesan, \& Hamzah, 2016). Auditor's independence positively affects audit quality (Windsor \&Warning-Rasmussen, 2009; Ilaboya \& Ohiokha, 2014).

\subsection{Audit Quality}

Quality of Audit has become important all over the world due to the collapse of some companies such as Enron, Worldcom in the United States and the issue of Cadbury in Nigeria (Eguasa \& Urhoghide, 2017). Audit quality can be defined in terms of technical competence and independence. These two qualities also add credibility to Accounting reports (Huang, 2006). Ame (2014) stated that audit quality could be seen as having two components: the ability to detect errors and misstatements and willingness to report them. According to Dang, (2004); Ding \& Jia (2012), audit quality is defined as the level to which the audit carried out meets the applicable auditing standards and regulations. Audit quality can be divided into two: the real quality of audit and audit quality based on opinion. Real audit quality sees the auditor as both noticing and reporting any major misstatements contained in the financial statements, while audit quality based on opinion refers to the viewpoints and opinion of various stakeholders about the auditors' ability to identify and communicate such misstatements (Dang, 2004). The quality of an audit will affect the reliability, credibility, and acceptability of financial reports (Eguasa \& Urhoghide, 2017). The Financial Reporting Council (FRC, 2008) noted that audit quality is dynamic, the indicators and drivers of audit quality change over time. The FRC gives five main drivers of audit quality: the audit firm's culture and personal qualities of the auditor, skills of staff and audit partners; the audit process effectiveness; the usefulness and reliability of audit reporting; and factors that affect audit quality outside the audit firm's control. (Eguasa \& Urhoghide, 2017). According to Aslan, \& Aslannertik (2017), audit quality is a concept that is structured by various factors such as audit firm leadership, knowledge/ experience/ tenure of the auditor, variety of services offered by the audit company, size in terms of being a big 4 or non-big 4 and reporting quality. There is a strong relationship between audit quality and auditor selection (Aslan, \& Aslannertik 2017). Audit quality directly affects the decision making of users of financial statements (De DeAngelo, 1981; Fuerman, 2003). According to Defond and Zhang (2014), auditors are responsible for assuring financial reporting quality as a result of professional auditing standards. According to Aslan \& Aslannertik (2017), the demand for high-quality audit stimulates the selection of the auditors through different factors but especially size, tenure, reputation, concentration, and price. Hauang, (2006) noted that Audit quality depends on the auditors' ability to carry out a thorough examination of the accounts and detect possible errors or anomalies (technical competence) and his willingness to provide opinion on them (independence). "Big 4" audit firms obtain premiums on audit fee (Francis, 1984; Francis, 1986; Wu, 2003) because clients believe that the "Big 4" have higher audit quality (Lennox, 1999; Krishnan, 2003). The Audit fee is the economic remuneration for auditors who provide audit services, which are an agency fee according to certain standards (Liu, 2017). Due to the frequent business failure coupled with incessant malpractices and increase in fraud techniques, there is a need for auditors to improve audit quality to address these negative occurrences (Okpala, 2015).

\section{Research Methodology}

The data for this study was adapted from a questionnaire on the determinant of the choice of auditor used by Olowookere \& Inneh (2016) in an article titled 'Determinants of Auditors choice in Nigerian quoted manufacturing companies' and an article written by Almer Philbrick, \& Rupley, 2014 titled “What Drives Auditor Selection?” The factors in the questionnaire include quality of the proposal, reputation for strong technical expertise, reputation for strong industry experience, accessibility of partner, identification, and address of accounting issues on a timely basis, proposed fee, range of non-audit services, referral by friends/ associates, owner's preference and long-term relationship. The questionnaire was based on a 5point Likert Scale ranging from Strongly Agree (5), to Strongly Disagree (1). The questionnaire was used to provide information on "Determinants of Auditors' selection among SMEs in Lagos metropolis" (Alaba, Ikeja, Lagos Island, and Surulere). Three hundred questionnaires were distributed with 75 distributed for each area; however, only 236 questionnaires were collected and analyzed.

\section{Results}

Questionnaires designed to understand the determinants of auditor's choice were distributed in four business regions of Lagos metropolis, Nigeria (Alaba, Ikeja, Lagos Island, and Surulere). Three hundred questionnaires were distributed with 75 distributed in each area; however, only 236 viable questionnaires were analyzed. The questionnaire was formulated using a Likert scale ranging from Strongly Agree (5) to Strongly Disagree (1). 


\begin{tabular}{|c|c|c|}
\hline Characteristic & Frequency & Percentage \\
\hline \multicolumn{3}{|l|}{ LOCATION } \\
\hline Alaba & 59 & $25 \%$ \\
\hline Ikeja & 52 & $22 \%$ \\
\hline Lagos Island & 51 & $22 \%$ \\
\hline Surulere & 74 & $31 \%$ \\
\hline \multicolumn{3}{|l|}{ GENDER } \\
\hline Female & 76 & $32 \%$ \\
\hline Male & 160 & $68 \%$ \\
\hline \multicolumn{3}{|c|}{ EDUCATIONAL QUALIFICATION } \\
\hline $\mathrm{BSC}$ & 219 & $93 \%$ \\
\hline Diploma & 8 & $3 \%$ \\
\hline High School & 2 & $1 \%$ \\
\hline MSc & 7 & $3 \%$ \\
\hline \multicolumn{3}{|l|}{ INDUSTRY } \\
\hline Trading & 88 & $37 \%$ \\
\hline Supermarket & 10 & $4 \%$ \\
\hline Photography & 4 & $2 \%$ \\
\hline Information Technology & 12 & $5 \%$ \\
\hline Interior Designs & 3 & $1 \%$ \\
\hline Health & 21 & $9 \%$ \\
\hline Food \&Beverage & 5 & $2 \%$ \\
\hline Fashion & 82 & $35 \%$ \\
\hline Entertainment & 4 & $2 \%$ \\
\hline Education & 3 & $1 \%$ \\
\hline Dry-cleaning & 2 & $1 \%$ \\
\hline Construction & 2 & $1 \%$ \\
\hline \multicolumn{3}{|l|}{ Number of Distinct Products } \\
\hline $1-5$ & 63 & $27 \%$ \\
\hline $6-9$ & 91 & $38 \%$ \\
\hline$\geq 10$ & 82 & $35 \%$ \\
\hline \multicolumn{3}{|l|}{ Number of Employees } \\
\hline $1-5$ & 154 & $65 \%$ \\
\hline $6-10$ & 82 & $35 \%$ \\
\hline \multicolumn{3}{|l|}{ Legal Status } \\
\hline Enterprise & 47 & $20 \%$ \\
\hline Limited & 189 & $80 \%$ \\
\hline \multicolumn{3}{|l|}{ Date of Commencement } \\
\hline $2000-2005$ & 19 & $8 \%$ \\
\hline $2006-2010$ & 99 & $42 \%$ \\
\hline $2011-2015$ & 102 & $43 \%$ \\
\hline $2016-2019$ & 16 & $7 \%$ \\
\hline Total & 236 & $100 \%$ \\
\hline
\end{tabular}

Table 1: Characteristics of Entrepreneurs

The table above shows the characteristics of the SME businesses interviewed in Lagos. Data were collected from four different locations in Lagos; highest number of viable responses (74) were collected from Surulere followed by Alaba with 59 viable responses, Ikeja (52) and Lagos Island (51). Majority of the SME business owners were male (68\%) while $32 \%$ were female. The population was seen to be an educated one as $93 \%$ of the business owners had a BSc degree, $3 \%$ had MSc degree, 3\% with Diploma while only 1\% of the entrepreneurs had high school certificate as highest educational qualification. The businesses were seen to operate in various sectors of the economy with Trading taking the lead at 37\%, followed by the Fashion industry (35\%), Health industry (9\%), Information Technology (5\%), Supermarkets (4\%), Food $(2 \%)$, Photography (2\%), Entertainment (2\%), Interior Design (1\%), Education (1\%), Dry-cleaning (1\%) and Construction (1\%). Majority of the entrepreneurs (38\%) had six to nine distinct products or services, $35 \%$ had ten or more products or services, while $27 \%$ had one to five distinct products or services. Majority of the entrepreneurs (65\%) also had between one to five employees, while $35 \%$ had between six to ten employees.

A vast majority of the SMEs (80\%) were limited liability companies while the remaining $20 \%$ were registered as business names. When asked the year they commenced their businesses, the majority (43\%) said they started between years 2011 and 2015, 42\% started within the years 2006 to 2010, 7\% started within the years 2016 to 2019 while 8\% within the years 2000 and 2005. 


\begin{tabular}{|c|c|c|c|}
\hline S/ N & Variable & Mean & Std Deviation \\
\hline 1 & Written proposal is high quality & 4.49 & 0.69 \\
$\mathbf{2}$ & Audit firm has reputation for strong technical expertise & 4.11 & 0.45 \\
$\mathbf{3}$ & Audit firm has reputation for strong industry experience & 4.14 & 0.40 \\
$\mathbf{4}$ & Partner is highly accessible & 4.19 & 0.76 \\
$\mathbf{5}$ & Partner identifies and addresses accounting issues on a timely & 4.21 & 0.76 \\
& basis & 3.84 & 0.72 \\
$\mathbf{6}$ & Proposed fee is significantly lower than other bidding firms & 4.16 & 0.43 \\
$\mathbf{7}$ & Audit firm offers a range of non-audit services & 4.74 & 0.45 \\
$\mathbf{8}$ & Referral by friends/ associates & 4.39 & 0.58 \\
$\mathbf{9}$ & Owners preference for specific auditor & 4.40 & 0.59 \\
\hline
\end{tabular}

Table 2: Statements on Determining Auditor's Choice

The respondents were asked to rank their level of agreement to statements on their criteria for choosing auditors. Results from analysis of their responses showed positive means ranging from 3.84 to 4.74 with a standard deviation between 0.40 and 0.76 . The top three determinants of auditor's choice amongst the respondents were "Referral by friends/ associates" with the highest mean (4.74) followed by "Written proposal is high quality" (4.49) and "Long term relationship with current auditor" (4.40); the statement "Proposed fee is significantly lower than other bidding firms" had the least mean (3.84).

\begin{tabular}{|c|c|c|c|c|c|}
\hline S/ N & Variable & \multicolumn{3}{|c|}{ Means } \\
\cline { 3 - 5 } & Alaba & Ikeja & Lagos Island & Surulere \\
\hline 1 & Written proposal is high quality & 4.83 & 4.17 & 4.51 & 4.42 \\
\hline 2 & $\begin{array}{c}\text { Audit firm has reputation for strong technical } \\
\text { expertise }\end{array}$ & 4.15 & 4.19 & 4.02 & 4.07 \\
\hline 3 & $\begin{array}{c}\text { Audit firm has reputation for strong industry } \\
\text { experience }\end{array}$ & 4.19 & 4.21 & 4.06 & 4.09 \\
\hline 4 & Partner is highly accessible & 4.22 & 4.15 & 4.18 & 4.22 \\
\hline 5 & $\begin{array}{c}\text { Partner identifies and addresses accounting issues } \\
\text { on a timely basis }\end{array}$ & 4.24 & 4.17 & 4.16 & 4.24 \\
\hline 6 & $\begin{array}{c}\text { Proposed fee is significantly lower than other } \\
\text { bidding firms }\end{array}$ & 3.85 & 3.98 & 3.65 & 3.86 \\
\hline 7 & Audit firm offers a range of non-audit services & 4.19 & 4.19 & 4.18 & 4.09 \\
\hline 8 & Referral by friends/ associates & 4.81 & 4.54 & 4.86 & 4.73 \\
\hline 9 & Owners preference for specific auditor & 4.42 & 4.54 & 4.22 & 4.38 \\
\hline 10 & Long term relationship with current auditor & 4.37 & 4.50 & 4.35 & 4.38 \\
\hline
\end{tabular}

Table 3: Comparing Means amongst Locations

Responses from each location were analysed to get their individual means on each statement presented in Table 3 above. Top three determinants of auditor's choice deferred across locations, as explained below:

- Alaba: "Written Proposal is high quality" topped with a mean of 4.83 followed by "Referral by friends/ associate" (4.81) and "Owners preference for specific auditor" (4.42).

- Ikeja: "Referral by friends/associates" and "Owners preference for specific auditor" topped with equal means (4.54) followed by "Long term relationship with current auditor" (4.50).

- Lagos Island: "Referral by friends/ associates" topped with 4.85 as mean followed by "Written proposal is high quality" (4.51) and "Long term relationship with current auditor" (4.35).

- Surulere: "Referral by friends/ associates" topped with mean of 4.73 followed by "Written proposal is high quality" (4.42); the statements "Owners' preference for specific auditor" and "long term relationship with current auditor" shared the third position with equal mean of 4.38 .

\section{Discussion and Conclusion}

The population of SME business owners was mainly male dominated, and this can be traced to the male gender dominance in the Alaba location which is popularly known as the trade center for technical appliances, gadgets or equipment in Lagos metropolis.

It was impressive to see that the population was a well educated one making it a viable one for the research question. The businesses were also majorly limited liability companies, thereby increasing the need for Auditors amongst respondents.

The trade and fashion industry were the most dominant in the population. The population also showed to be an experienced one in entrepreneurship as most of the companies commenced before the year 2015. The results of the analysis showed referral, quality of the written proposal, and relationship to be strong determinants of auditor's choice amongst the SME businesses both generally and across locations. Relationship, in this case, covers owners' preference for auditor and long-term relationship. Although the Alaba businesses were most particular about the quality of written 
proposal than the businesses in other locations which might infer that they are more objective, it was also clear that referral and relationship was still part of their top determinants.

Across all locations and generally, the statement "Proposed fee is significantly lower than other bidding firms" had the least mean which shows that the respondents were mostly more concerned about the quality of audit service than price. In conclusion, it can be inferred that the following factors are the determinants of auditor's choice among SME businesses in Lagos state:

- Referral by friends and associates.

- Quality of written proposal

- Long term relationship with the current auditor.

- Owner's preference for specific auditor.

\section{References}

i. Abdul Ganiyu, A. (2013). Audit Practice in Global Perspective: Present and Future Challenges. Research Journal of Finance and Accounting, 4(6). 1-5. Retrieved from www.researchgate.net

ii. Abe, M., \& Proksch, M., (2017). Supporting participation of Asia-Pacific SMEs in global value chains. Journal of Korea Trade, 21(2), 86-106. Retrieved from www.emeraldinsight.com

iii. Abid, A., Shaique, M. \& Haq. M. A. (2018). Do big four auditors always provide higher audit quality? Evidence from Pakistan. International Journal of Financial Studies, 6(58), 2-22. doi:10.3390/ijfs6020058

iv. Abu Bakar, N. B., Abdul Rahman, A. R., \& Abdul Rashid, H. M. (2005). Factors influencing auditor independence: Malaysian loan officers' perceptions. Managerial Auditing Journal, 20, 804-822. doi:10.1108/ 02686900510619665

v. Abu Bakar, N. B., \& Ahmad, M. (2009). Auditor independence: Malaysian accountants' perceptions. International Journal of Business and Management, 4(12), 129-141. doi:10.5539/ ijbm.v4n12p129

vi. Abdul Nasser, A.T., Mustapha, S. N. \& M. Hudaib (2006). Auditor-client relationship: The case of audit tenure and auditor switching in Malaysia. Managerial Auditing Journal, 21 (7), 724-737. doi: 10.1108/ 02686900610680512

vii. Acho, Y. \& Abuh, A. P. (2018). Assessment of the contributions of small scale enterprises to the development of the Nigerian economy. Journal of Good Governance and Sustainable Development in Africa, 4, 37-47. Retrieved from www.rcmss.com

viii. Adebisi, J. F., \& Gbegi, D. O., (2013). Effects of multiple taxations on the performance of small and medium scale business enterprises (A study of West Africa Ceramics Ajeokuta, Kogi State). Mediterranean Journal of Social Sciences, 4(6), 324-334. doi:10.5901/ mjss. 2013.v4n6p323

ix. Adeyemi, S. B. \& Olowookere, J. K.(2011). Stakeholders' perception of audit performance gap in Nigeria. International Journal of Accounting and Financial Reporting, 1,152-172. Retrieved from www.macrothink.org

x. Adeyemi, S.B. \& Okpala O. (2011). The Impact of audit independence on financial reporting: Evidence from Nigeria. Business and Management Review, 1(4), 9-25. Retrieved from www.eajournals.org

xi. Akinwale, Y. O. \& Adepoju, A. O. (2019). Factors influencing willingness to adopt renewable energy technologies among micro and small enterprises in Lagos State Nigeria. International Journal of Sustainable Energy Planning and Management,19, 69-82.doi:10.5278/ ijsepm.2019.19.7

xii. Akpom, U.N \& Dimkpah, Y. O. (2013). Determinants of auditor independence: A comparison of the perceptions of auditors and non-auditors in Lagos, Nigeria. Journal of Finance and Accountancy, 11-17. Retrieved from www.aabri.com

xiii. Al-Ajmi, J. (2010). Perceptions of auditors and financial-statement users regarding auditor independence in Bahrain. Managerial Auditing Journal, 26(2), 130-160.doi: doi:10.1108/ 02686901111095010.

xiv. Almer, E.D., Philbrick, D. R. \& Rupley, K. H. (2014). What drives auditor selection? American Accounting Association, 8, A26-A42. doi: 10.2308/ ciia-50779

xv. Ajayi, C. A. (1997). The Development of Accounting Profession in Nigeria. Published in Accounting Education in Nigeria: Challenges and Prospects - A Publication of the Society of Women Accountants of Nigeria (SWAN)

xvi. Ame, J. O. (2014). Audit committee effectiveness and audit quality of Nigerian money deposit Banks. Accounting and Finance research association. www.afra.org.ng

xvii. Anderson, B., Maletta, M. \& Wright, A. (1998). Perceptions of auditor responsibility: Views of the judiciary and the profession. International Journal of Auditing, 2(3): 215-32. doi: 10.1111/ 1099-1123.00041

xviii. Aslan, E., Aslanertik, B. E. (2017). The determinants of auditor selection in terms of firm and IPO characteristics: Evidence from BIST. Journal Accounting and Management, 7, 64-74. Retrieved from journals.univ-danubius.ro

xix. Babatolu, A. T. , Aigienohuwa, O. O.\& Uniamikogbo, E. (2016. ). Auditor's independence and audit quality: A study of selected deposit money banks in Nigeria. International Journal of Finance and Accounting, 5(1): 13-21 doi: 10.5923/ j.jfa.20160501.02

xx. Baldacchino, P. J., Caruana, R., Grima, S. \& Bezzina, F. H. (2017). Selected behavioural factors in client-initiated auditor changes: The client-auditor perspectives. European Research Studies Journal, 20(2), 16 47. Retrieved from www.um.edu.mt

xxi. Bamber, M. E. \& Venkataraman, I. M. (2007). Auditors' identification with their clients and its effect on auditors' objectivity. 26(2). Auditing: A Journal of Practice \& Theory, 26, (2), 1-24. doi:10.2308/ aud.2007.26.2.1

xxii. Barkes, L., Simnett, R., \& Urquhart, P., (2002). The effect of client fee dependence on audit independence. Australian Accounting Review, 12(3), 14-22. doi:10.1111/j.1835-2561.2003.tb00207.x 
xxiii. Boldeanu, T. F., Tache. I. (2016). The financial system of the EU and the capital markets Union. European Research Studies Journal, 19, 60-70. Retrieved from www.ersj.eu

xxiv. Budik, J., and Schlossberger, O. (2015). Processes and technologies for identifying illegal financial operations. International Journal of Economics and Business Administration, 3(2), 22-31. Retrieved from www.um.edu.mt

xxv. Cameran, M., Prencipe, A. \& Trombetta, M. (2014). Mandatory audit firm rotation and audit quality. Journal European Accounting Review, 25, 35-58. doi:10.1080/ 09638180.2014.921446

xxvi. Choi, J. H., Kim, C., Kim, J. B., and Zang, Y. (2010). Audit office size, audit quality, and audit pricing. Auditing: A Journal of Practice \& Theory, 29(1), 73-97. Retrieved from ink.library.smu.edu.sg

xxvii. Collis, J. Jarvis, R. \& Skerratt, L. (2004) The demand for the audit in small companies in the UK, Accounting and Business Research, 34:2, 87-100, doi:10.1080/ 00014788.2004.9729955

xxviii. Dang, L. (2004). Assessing actual audit quality. Ph.D. Thesis, Faculty of Drexel University

xxix. DeAngelo, L.E., (1981). Auditor size and audit quality. Journal of Accounting and Economics, 3(3), 183-199. doi: 10.1016/ 0165-4101(81)900Deakins02-1

xxx. DeFond, M; Erkens, D.H. \& Zhang, J. (2014). Do client characteristics really drive the big N Effect? Evidence from matching methods. Working paper. University of Southern California

xxxi. De Ruyter, K. \& Wetzels, M. (1999). Commitment in auditor-client relationships: Antecedents and consequences. Accounting, Organisations and Society, 24, 57-75. doi:10.1016/ S0361-3682(98)00008-7

xxxii. Ding, Y., \& Jia, Y. (2012). Auditor mergers, audit quality, and audit fees: Evidence from the PricewaterhouseCoopers merger in the UK. Journal of Accounting and Public Policy, 31(2), 69-85. doi:10.1016/j.jaccpubpol.2011.08.002

xxxiii. Ebo, B. O. (2016) auditors' independence and audit quality in Nigeria. Continental Journal Social Sciences, 9,37 48, 2016. doi:10.5707/ cjsocsci.2016.9.1.37.48

xxxiv. Eguasa, B. K. \& Urhoghide, R. O. (2017). Audit market concentration and audit quality in Nigeria. Journal of Business and Management, 19(9), 01-09. doi:10.9790/ 487X-1909040109

xxxv. Eluyela, D. F. \& Ilogho, S. O. (2016). Audit standards and performance of auditors': Evidence from Nigerian banking industry. 3rd International Conference on African Development Issues. Department of Accounting School of Business, College of Development Studies Covenant University, Ota Ogun State, Nigeria

xxxvi. Evangelia, S. (2013). Determinants of auditor choice in the European market. Master Thesis. School of Ecconomics and Business Administration. International Hellenic University.

xxxvii. Federation of European Accountants :FEEA (2013). Auditor selection. Towards best practices. Auditor selection towards best practices. 4-29. Retrieved from www.kacr.cz

xxxviii. Fuerman, R.D., (2003). Audit quality examined one large CPA firm at a time: Empirical evidence of a precursor of Arthur Andersen's collapse. Retrieved from www.papers.ssrn.com

xxxix. Fontaine, R., Herda, D. \& Letaifa, S.B. (2013). What audit clients want: Lessons learned from an interview study to understand the reasons clients change audit firms and the client's perceived value of the audit service. Current Issues In Auditing, 7(1). 1-A14. Retrieved from www.aaapubs.org

xl. Francis, J.R. (1984) The effect of audit firm size on audit prices: A study of the Australian market. Journal of Accounting and Economics , 6, 133-151. Retrieved from econpapers.repec.org

xli. Francis, J.R. and Stokes, D.J. (1986) Audit Prices, Product Differentiation, and Scale Economies: Further Evidence from the Australian Market. Journal of Accounting Research , 24, 383-393. doi:10.2307/ 2491141

xlii. Gahman, S.S. \& Ali, A. A. (2015). Determinants of financial audit in small and medium enterprises In Kenya A survey of audit firms in Mombasa. Journal of Business and Management,17(5), 135-145, retrieved from www.iosrjournals.org

xliii. Gul, F. A., (1991). Size of audit fees and perceptions of auditors' ability to resist management pressure in audit conflict situations. Abacus, 27(2), 162-172. doi.10.1111/j.1467-6281.1991.tb00264.x

xliv. Grima, S., Romānova, I., Bezzina, F. \& Dimech, C.F. (2016). Alternative investment fund managers directive and its impact on Malta's financial service industry. International Journal of Economics and Business Administration, 4, 70-85. Retrieved from www.ersj.eu

xlv. Haron, H., Ismail, I., Ganesan, Y. \& Hamzah, Z. (2016). Audit exemption for small and medium enterprise: Perceptions of Malaysian auditors. Asian Academy of Management Journal 21(2):153-182. Doi: 10.21315/ aamj2016.21.2.7

xlvi. Huang, J., ( 2006). An investigation into the determinants of auditor selection and audit fees in China. Ph.D. Thesis, Cardiff University. Retrieved from www.orca.cf.ac.uk

xlvii. Ilaboya O.J. \& Ohiokha F. I. (2014). Audit firm characteristics and audit quality in Nigeria. International Journal of Business and Economics Research, 3 (5), 187-195. doi: 10.11648/j.j.jber.20140305.14

xlviii. Ikharo, C.O., (2015). The impact of Auditor's tenure on quality audit report. Research Journal of Finance and Accounting, 6, 91-96. Retrieved from www.iiste.org

xlix. Jeong, S.W., \& Rho, J., (2004). Big six auditors and audit quality: The Korean evidence. The International Journal of Accounting, 39 (2), 175-196. doi:10.1016/j.intacc.2004.02.001

1. Kehinde, O.J., Abiodun, A.J. Adegbuyi, O., and Oladimeji, H. (2016). Small and Medium Scale Enterprises: Pivotal to Sustainable Economic Development: The Nigeria Experience. International Journal of Current Research, 8, xxxxxxxxxx. Retrieved from www.eprints.covenantuniversity.edu.ng

li. Krishnan, G.V. (2003) Audit quality and the pricing of discretionary accruals. Auditing: A Journal of Practice \& Theory, 22, 109-126. doi:10.2308/ aud.2003.22.1.109 
lii. Kleinman, G. \& Palmon, D. (2001). Understanding auditor-client relationships: A multi- faceted analysis. Princeton: Markus Wiener Publishers.

liii. Knechel, W. R., (2002). The role of independent accountant in effective risk management. Tijdschrift voor Economic en Management, 65-86. Retrieved from ideas.repec.org

liv. Knechel, W. R., Niemi, L. \& Sundgren, S. (2008), Determinants of auditor choice: Evidence from a small client market. International Journal of Auditing, 12,65-88. doi: 10.1111/j.1099-1123.2008.00370.x

lv. Lal Joshi, P., Al Ajmi, J. \& Bremser, W.G. (2009). A study of auditor-client relationships and problems in the Bahraini audit environment. Advances in Accounting, incorporating Advances in International Accounting .25, 266-277. doi:10.1016/j.adiac.2009.08.003

lvi. Lennox, C. S. \& Pittman, J. A. (2011). Voluntary audits versus mandatory audits. American Accounting Association,86(5)1655-1678. doi: 10.2308/ accr-10098

lvii. Limperg, T., (1932). The social responsibility of the auditor. Reproduced in Limperg

lviii. Institute; (1985).The New Zealand: Limperg Institute

lix. Lin, Z, Liu J. M. (2009). The impact of corporate governance on auditor choice: Evidence from China. Journal of International Accounting, Auditing, and Taxation, 18, 44-59. doi:10.1016/ j.intaccaudtax.2008.12.005

lx. Lin, L. \& Tepalagul, N. K. (2014). Auditor independence and audit quality: A Literature review. Journal of Accounting, Auditing \& Finance, 30, 101-121 doi:10.1177/ 0148558X14544505.

lxi. Liu, S.H. (2017). An empirical study: Auditors' characteristics and audit fee. Open Journal of Accounting, 6, 52-70. doi:10.4236/ ojacct.2017.62005

lxii. Neirotti, P., Raguseo, E., \& Paolucci, E. (2018). How SMEs develop ICT-based capabilities in response to their environment: Past evidence and implications for the uptake of the new ICT paradigm. Journal of Enterprise Information Management, 31, 10-37. Retrieved from www.emeraldinsight.com

lxiii. Ohiokha, F. I. \& Akhalumeh, P. B. (2013). Auditing standards and auditors performance: the Nigerian experience. European Journal of Accounting Auditing and Finance Research, 1(3), 15-23. Retrieved from www.eajournals.org

lxiv. Olagunju, A. (2011). An empirical analysis of the impact of auditors independence on the credibility of financial statement in Nigeria. Research Journal of Finance and Accounting, 2(3). 82-98. Retrieved from www.iiste.org

lxv. Olowookere, J. K., Inneh, G. E. (2016). Determinants of auditor's choice in Nigerian quoted manufacturing companies. Research Journal of Finance and Accounting, 7(6), 49-57. Retrieved from www.iiste.org

lxvi. Okpala, K. E. (2015). Stamatis generic model and audit quality in Nigeria. The Journal of Social Sciences Research. The Journal of Social Sciences Research,1(8): 94-101. Retrieved from

lxvii. Owolabi, S. A., Jayeoba, O. O. \& Ajibade, A. T. (2016). Evolution and development of auditing. Unique Journal of Business Management Research, 3, 032-040. Retrieved from www.researchgate.net

lxviii. Power, M. (1999). The Audit Society: Rituals of Verification. Oxford: Oxford University Press

lxix. Rahman, M., Uddin, M., \& Lodorfos, G. (2017). Barriers to enter in foreign markets: evidence from SMEs in emerging market. International Marketing Review, 34, 68-86. Retrieved from www.emeraldinsight.com

lxx. Rupeika-Apoga, R. and Nedovis Uraev, R. (2015). The foreign exchange exposure of non- financial companies in Eurozone: myth or reality? International Journal of Economics and Business Administration, 3, 54-66. Retrieved from ideas.repec.org

lxxi. Small and Medium Enterprises Development Agency of Nigeria: SMEDAN. (2013). SMEDAN and national bureau of statistics collaborative survey: Selected findings 2013. Abuja: National Bureau of Statistics. Small and Medium Enterprises Development Agency of Nigeria. Retrieved from www.nigerianstat.gov.ng

lxxii. Suryanto, T. (2016). Audit delay and its implication for fraudulent financial reporting: A study of companies listed in the Indonesian stock exchange. European Research Studies Journal, 19, 18-31. Retrieved from ideas.repec.org

lxxiii. Tanko, M. (2011).Audit Expectation Gap: The Trend to Close the Gap in the 21st Century. Research commissioned by The Institute of Chartered Accountants of Nigeria (ICAN).

lxxiv. Thalassinos, I.E., and Liapis K. (2014). Segmental financial reporting and the internationalization of the banking sector. Chapter book in, Risk Management: Strategies for Economic Development and Challenges in the Financial System,(eds), D. Milos Sprcic, Nova Publishers

lxxv. Theriou, G.N., (2015). Strategic management process and the importance of structured formality, financial, and non-financial information. European Research Studies Journal, 18(2), 3-28. Retrieved from ideas.repec.org

lxxvi. Wallace, W., (1981). The Economic Role of the Audit in Free and Regulated Markets, Open Educational Resources, 2, 7-15. Retrieved from scholarworks.wm.edu

lxxvii. Windor, C. \& Warning-Rasmussen, B. (2009). The rise of regulatory capitalism and the decline of auditor independence: A critical and experimental examination of auditor's conflicts of interests. Critical Perception of Accounting, 20(2), 26 -288. doi: 10.1016/j.cpa.2007.04.003

lxxviii. Wu, L. (2003) The Determinants of audit fee: Evidence from Chinese stock market's first-time disclosure of audit fee. China Accounting Review, 1, 113-128. Retrieved from www.scirp.org

lxxix. Zhang T, Bin S, Zhang H (2010). Political Connection, transparency, and auditor choice: Evidence from familyowned firms in China. China Journal Account. Research. 17-18. Retrieved from www.cb.cityu.edu.hk 